\title{
Cultivation of "Roxo de Valinhos" Fig Tree in Different Plant Densities for Production of Green Figs for Industry in the Region of Campo Das Vertentes-MG
}

\author{
Paulo Márcio Norberto ${ }^{1}$, Ângelo Albérico Alvarenga ${ }^{1^{*} \text {, }}$ \\ José Clelio de Andrade ${ }^{1}$, Filipe Almendagna Rodrigues ${ }^{2}$, \\ Lair Victor Pereira' ${ }^{1}$ Emerson Dias Gonçalves ${ }^{1}$ \\ ${ }^{1}$ Company of Farming Research of Minas Gerais-EPAMIG, Lavras, Brazil \\ ${ }^{2}$ Federal University of Lavras-UFLA, Lavras, Brazil \\ Email: *angelo@epamig.ufla.br
}

How to cite this paper: Norberto, P.M., Alvarenga, Â.A., de Andrade, J.C., Rodrigues, F.A., Pereira, L.V. and Gonçalves, E.D. (2018) Cultivation of "Roxo de Valinhos" Fig Tree in Different Plant Densities for Production of Green Figs for Industry in the Region of Campo Das Vertentes-MG. Agricultural Sciences, 9, 1097-1106.

https://doi.org/10.4236/as.2018.99076

Received: July 16, 2018

Accepted: September 1, 2018

Published: September 4, 2018

Copyright $\odot 2018$ by authors and Scientific Research Publishing Inc. This work is licensed under the Creative Commons Attribution International License (CC BY 4.0).

http://creativecommons.org/licenses/by/4.0/

\section{(c) (i) Open Access}

\begin{abstract}
The objective of this work was to study the effect of different planting densities on the development and production of "Roxo de Valinhos" green figs for industry, in the Campo das Vertentes-MG region. The experiment was installed at the Risoleta Neves Experimental Field-CERN/EPAMIG. The plants used were three years old and were arranged in three randomized blocks, subject to three different planting densities, with spacings ranging from $1 \mathrm{~m}$ (4000 plants.ha $\left.{ }^{-1}\right), 1.5 \mathrm{~m}$ (2666 plants.ha $\left.{ }^{-1}\right)$, and $2 \mathrm{~m}(2000$ plants.ha $\mathrm{h}^{-1}$ ) between plants in the planting line and $2.5 \mathrm{~m}$ between row for all planting densities. The average length of the branches (m), average number of fruits per branch, average number of fruits per plant, average weight of fruits, average yield per plant and the average yield per hectare $(\mathrm{kg})$ were evaluated. It was verified that, there were no significant differences in the length of branch and in the average weight of fruit, in the three densities of fig tree planting. (4000 plants.ha ${ }^{-1}$ ), the average number of fruits per branch (7.5), per plant (55.87) and yield per plant $(878.93 \mathrm{~kg})$ were lower, however. The average yield per hectare $(3515.73 \mathrm{~kg})$ was higher than in other growing densities. It is concluded that, the higher density of plants (4000 plants.ha $\left.{ }^{-1}\right)$, provides the highest productivity per area, without damages to the quality of the fruits.
\end{abstract}

\section{Keywords}

Planting Densities, Agroindustry, Ficus carica L. 


\section{Introduction}

Currently, the largest fig producers in the world are Egypt and Algeria. Brazil, in turn, is the largest producer of figs in the Southern Hemisphere, with a cultivated area of approximately 3020 ha, with the seventh largest production in the world $(26,476 \mathrm{t})$ and the fifth highest productivity $\left(8.76 \mathrm{t} \cdot \mathrm{ha}^{-1}\right)$ if ranking as one of the largest producers and the main exporter of fresh fig fruit to the Egyptian, Turkish and Lebanese market, the world's largest fruit consumers [1].

Fruit growing is a sector of agriculture that is expanding worldwide, mainly due to the notoriety that has been given to healthier and more functional foods; the per capita fruit consumption in Brazil is of the order of $57 \mathrm{~kg} / \mathrm{year}$, index far below developed countries like Italy and Spain with $114 \mathrm{~kg}$ and $120 \mathrm{~kg}$, respectively. Only this data shows how much the country needs to invest in the production of fruits in quality and quantity, besides being an extremely important activity, it moves many markets, generates large amounts in currencies and jobs [1] [2].

The cultivation of the fig tree in Brazil is practically based on the planting of the cultivar Roxo de Valinhos. Rio Grande do Sul is the largest Brazilian producer, followed by Minas Gerais, both with production focused on industrialization; the state of São Paulo is the third largest producer of fig, but it is worth mentioning that it is the most important producer state of country table fig [2].

Fruit trees in general, and not differently in fig tree crop, determine better plant density, closely related to optimization of fruit quality and maximization of yield [3]. Of the factors involved in agricultural productivity, photosynthesis is the most determinant. The elevation of photosynthesis rates depends, among other factors, on the maximum utilization of available light, which can be obtained by cultural manipulation. The simplest form of cultural manipulation comprises a population of plants more suited to the purpose of economic exploitation [4].

According to [5], the planting spacing of the fig tree can vary depending on factors such as soil fertility, topography, number of branches driven by plant, level of mechanization and production objective. The different combinations of these factors allow a wide range of spacings.

In this context, the objective of this work was to evaluate the effect of different planting densities of fig tree (Ficus carica L.) on the development and production of green figs in the region of Campo das Vertentes-MG, providing more abundant crops, rawer material for the agroindustries of the region, making it a good option to generate employment and income for the small producer.

\section{Material and Methods}

The experiments were carried out in the premises at the Risoleta Neves Experimental Field belonging to Company of Farming Research of Minas Gerais (EPAMIG), in partnership with the Federal University of São João Del Rei-UFSJ, with geographic coordinates of $21^{\circ} 06^{\prime} 25.0^{\prime \prime S} 44^{\circ} 14^{\prime} 53.8^{\prime \prime} \mathrm{W}$ and 898 
$\mathrm{m}$ altitude. According to the [2], the place is classified as tropical climate of altitude (Cwa), that is, subtropical climate, with cold and dry winter, and hot and humid summer. The soil of the experimental area is classified as Red Latosol Distrophic. The agricultural seasons 2009/2010 and 2010/2011 were analyzed, period comprised in each harvest, of July to March. The cultivar used was "Roxo de Valinhos", introduced in Brazil at the beginning of the last century by the Italian Lino Bussato, in the city of Valinhos (SP), originating from the variety "Brown Turkey", whose fig is dark purple in color and in honor of the municipality, was then given the designation "Purple of Valinhos". This cultivar presents fruits with about 60 to 90 grams when ripe, great flavor for consumption to the natural, besides being used when green for industrialization.

Plants with about 3 years of age were used, and the planting arranged in three blocks, being the plants submitted to three different planting densities, with spacings ranging from $1.0 \mathrm{~m}$ (4000 plants.ha $\left.{ }^{-1}\right), 1.5 \mathrm{~m}$ (2666 plants.ha $\left.{ }^{-1}\right)$, and 2.0 $\mathrm{m}\left(2000\right.$ plants.ha $\left.\mathrm{a}^{-1}\right)$ between plants in the planting line and $2.5 \mathrm{~m}$ between rows for all systems. The experimental design was a randomized block design, with three replications, each replicate being composed of five plants, totaling 45 plants.

In the two harvests analyzed, the plants underwent the winter pruning of production in the last week of July of each agricultural year and received a winter fertilization, the base of $500 \mathrm{~g}$ of simple superphosphate plus ten liters of manure of well-tanned corral. The plants were pruned drastically with the aid of pruning shears, leaving only three "legs" per plant, measuring $15 \mathrm{~cm}$ each, to protect the cuts, the brush was done with the paste. About one month after pruning, periodic sprouts were done, leaving only two shoots per branch, making a total of six sprouts that gave rise to six productive branches per plant. As cultural treatments of the experimental area, the soil was kept clean along the line of planting and brushing between the lines, the plants were not irrigated and the weed management was done through weeding and the use of herbicides; maintenance fertilization was carried out, providing phosphorus and organic matter in the month of June, with plants still dormant and fertilization in cover after pruning, when the shoots were about $5 \mathrm{~cm}$; Phytosanitary treatments, especially for the control of rust (Cerotelium fici) were carried out according to the need throughout the vegetative period of the plant. The evaluated characteristics were: a) Average length of the branches ( $m$ ): Determined by the measurement of the branches, at the end of the vegetative cycle; $b$ ) Average number of fruits per branch: Determined by counting the fruits in the branches, during the first harvest; c) Average number of fruits per plant: The fruits were counted per plant at different planting densities; d) Average weight of fruits (g): It was determined by weighing the fruits in the different treatments; e) Average yield per plant: Obtained in the six initial branches of the plant to obtain the first harvest, which started when at least $80 \%$ of the fruits presented with the characteristic of firmness, thus determining the ideal point of harvest of the fruits for industry; f) Av- 
erage yield per hectare $(\mathrm{kg})$ : Obtained in $\mathrm{kg}$, it was estimated to one hectare, according to the number of plants of each planting density. The data were submitted to analysis of variance by the $\mathrm{F}$ test and compared to each other by the Tukey test at the $5 \%$ level of significance. Statistical analysis was performed through the SISVAR program [6].

\section{Results and Discussion}

\subsection{Average Length of Branches (m)}

Through the analysis of variance, and the mean test, it was possible to verify that there was no significant difference in relation to the final mean branch length variable, in the different planting densities (Figure 1). with a depth of $1.0 \mathrm{~m}$ between plants and $2.5 \mathrm{~m}$ between rows, providing a density of 4000 plants per ha, and the treatment with greater spacing $2.0 \mathrm{~m}$ between plants and $2.5 \mathrm{~m}$ between rows promoting a lower density of plants per area (2000 plants.ha $\left.{ }^{-1}\right)$. In general, the growth of branches in the plants submitted to three planting densities was satisfactory and relatively homogeneous throughout the crop cycle. However, a hypothesis can be commented on, although the differences between the length of branches have not been significant, it was noticeably noticed that when the plants were conducted more density ( 4000 plants $\left.\mathrm{ha}^{-1}\right)$, it was verified that the internodes of the branches were longer, shorter, perhaps due to a greater competition for luminosity and aeration in the fig tree. This tendency of greater growth in the branches of the more density planted plants, although not statistically verified in the work in question, [7], found that the plants conducted in the lowest tested spacing, $0.5 \mathrm{~m}$ between plants, with a planting density of 3333 plants. $\mathrm{ha}^{-1}$ the growth of branches was higher than in the other spacings, with lower density of plants per area, in turn competing less for water, light and nutrients. [8],

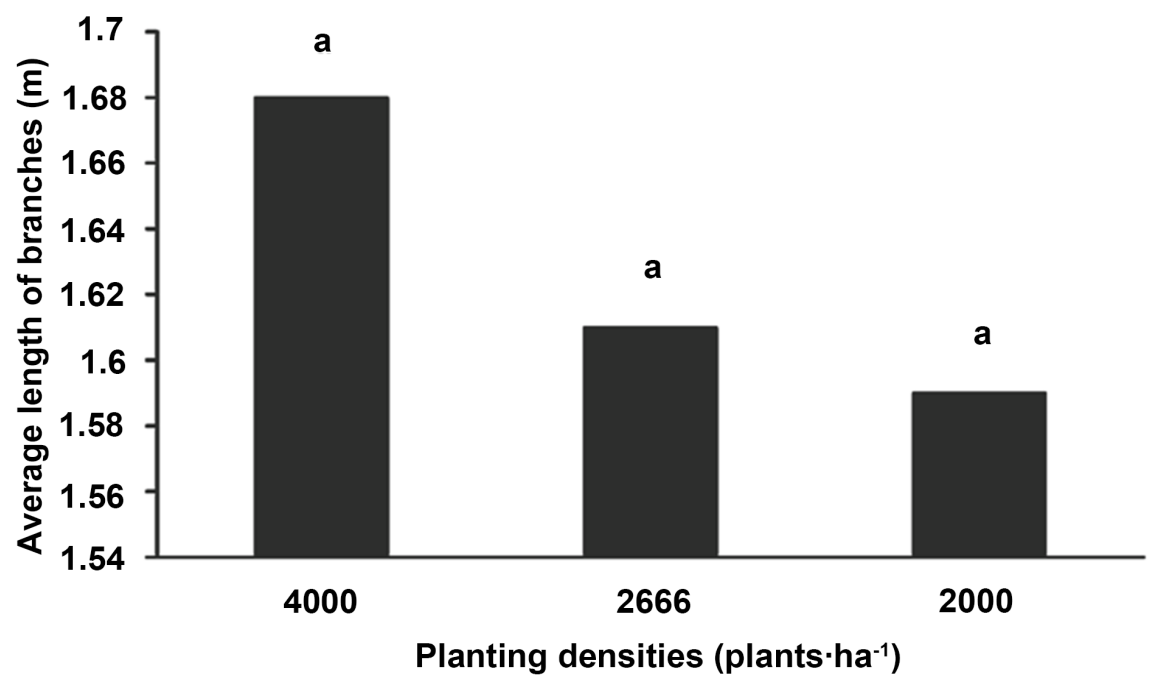

Figure 1. Average length of branches $(\mathrm{m})$ in three planting densities of fig tree $\mathrm{cv}$. Roxo de Valinhos. Means followed by distinct letters on the column, differ significantly from each other by the Tukey test at the $5 \%$ level of significance. C.V. $=7.76 \%$. 
evaluating the production of green figs in plants with 16 to 32 branches, also observed that the higher the number of branches, the smaller the growth of the same ones, since the competition of the branches by photo assimilates is greater.

\subsection{Number and Average Weight of Fruits per Branch}

For the variable average number of fruits per branch, according to Figure 2, it was verified that there was a significant difference between the lowest density (1 $\mathrm{m}$ ) and the others. Thus, when the plants were conducted at the lowest spacing and consequently with the highest plant density, (4000 plants.ha $\left.{ }^{-1}\right)$, a lower number of fruits were observed per branch (7.5), however, as the number of plants per area in this spacing is higher, productivity per area is not affected, due to the lower production of fruits per branch. However, when the plants were grown in the larger plant spacings of $1.5 \mathrm{~m}$ and $2.0 \mathrm{~m}$ between plants with plant densities of 2666 plants per ha and 2000 plants per ha respectively, the highest number of fruits per branch with 9.9 and 10.8 fruits per branch was observed in relation to the lower planting density. [9] also verified that the highest number of fruits per plant occurred in plants with 18 and 21 productive branches, however, there was a higher average yield of fruits per branch in plants conducted with 6 productive branches, and this production declined numerically in increase in the number of productive branches per plant. A similar result was observed by [7], found that the plants spaced in $2 \mathrm{~m}$ presented the best results, with 12.21 fruits per meter of branch, but differing statistically only from the systems conducted with 0.5 and $1.0 \mathrm{~m}$ between plants, with 7, 27 and 9.44 fruits per meter of branch. As for the average fruit weight, as a complementary data, it was verified that there was no statistical significance for this characteristic of the fruit, at the three different planting densities, the fruits harvested green for industry, when all internal cavity of the same were completely full, giving firmness to the fruit. [10] studying the influence of irrigation and the number of branches $(18,27,36$ and 45) per plant in the production of green figs from cv. Roxo de Valinhos, verified that in the treatments with 18, 27 and 36 branches the number and total weight of fruits increased with the increase of the number of branches. The mean weight of the fruits was not affected, and [11], in the São Francisco Valley-PE, verified that the total number of green figs increased with the increase of the number of branches up to 32 , decreasing when it was increased to 48 , and the average weight of the fruits was not affected.

\subsection{Average Number of Fruits per Plant}

It is observed in Figure 3 that there were significant differences between the spacing of $1 \mathrm{~m}$ between plants, whose plant density was 4000 plants.ha ${ }^{-1}$, producing on average 55.87 fruits per plant, in relation to the other 2666 plants.ha $^{-1}$ and 2000 plants.ha ${ }^{-1}$, producing 66.33 and 64.33 fruits/plant, respectively. However, although the number of fruits per plant obtained in the spacing of 1 $\mathrm{m}$, is lower than in the other spacings, when considering the density of 


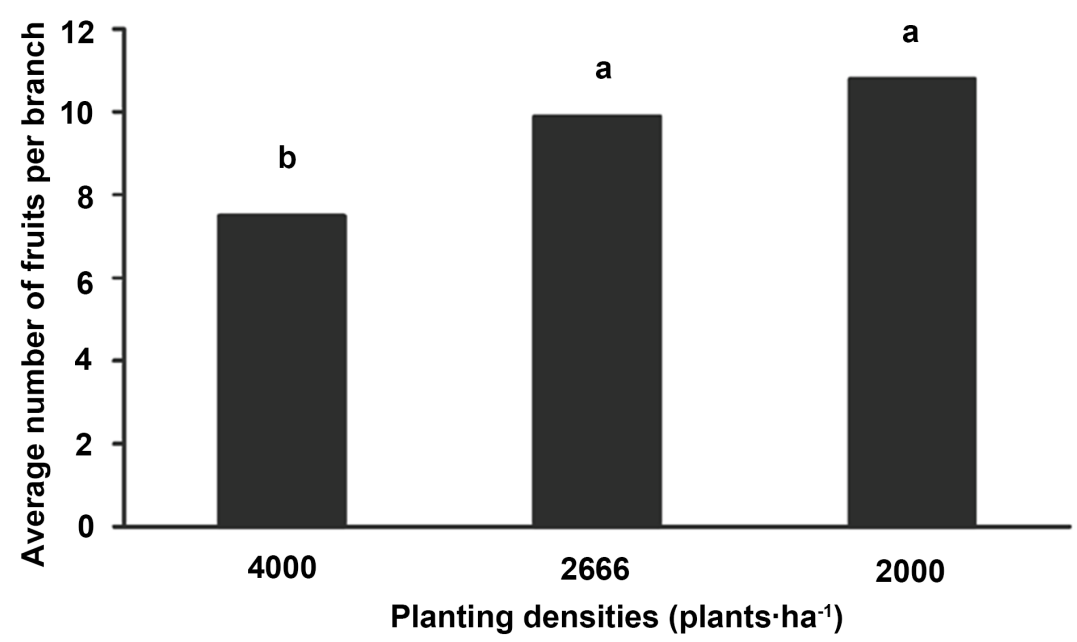

(a)

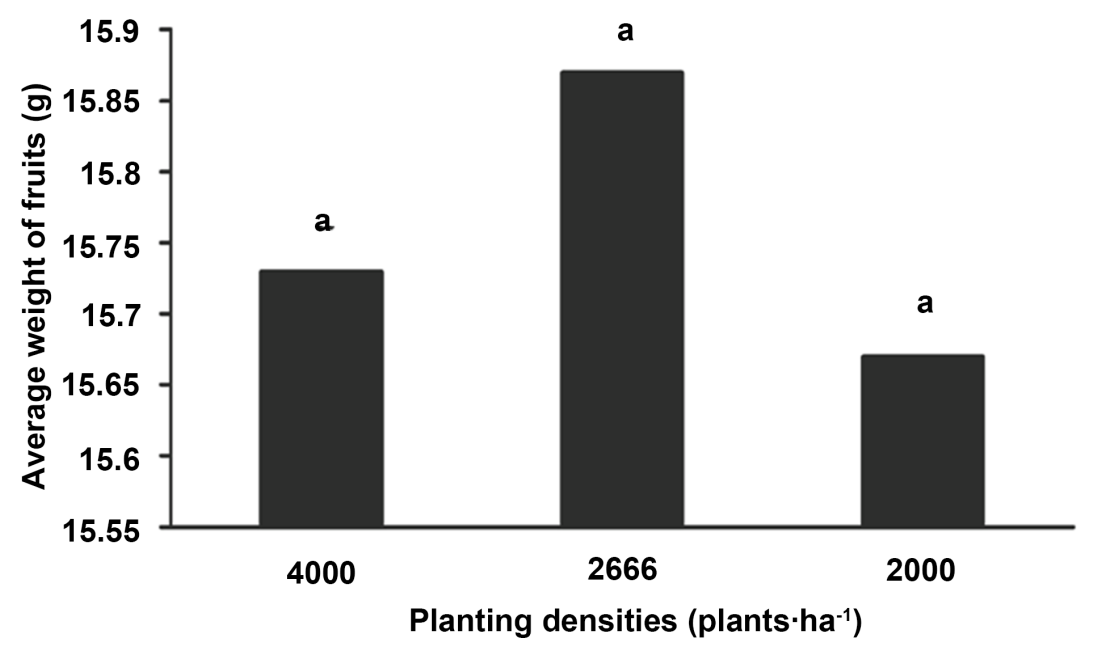

(b)

Figure 2. (a) Average number of fruits per branch and (b) Average weight of fruits ( $g$ ) in three planting densities of fig tree cv. Roxo de Valinhos. Means followed by distinct letters on the column, differ significantly from each other by the Tukey test at the $5 \%$ level of significance. (a) C.V. $=8.32 \%$ and (b) C.V. $=13.95 \%$.

(4000 plants.ha ${ }^{-1}$ ), with the fruits presenting an average weight of $15.73 \mathrm{~g}$ a production of green figs per ha is $\left(3515.34 \mathrm{~kg} \cdot \mathrm{ha}^{-1}\right)$, that is, much larger than in the other farms. [7] also verified that the highest number of fruits accumulated in the year per meter of branch was in the plants spaced in $2.0 \mathrm{~m}$ and presented the best results, with 12.21 fruits per meter of branch, differing statistically from the systems conducted with 0,5 and $1.0 \mathrm{~m}$ between plants, with 7.26 and 9.44 fruits per branch, respectively. These results were higher than those obtained by [12], which obtained, in an orchard conducted with 24 branches per plant, 6.38 fruit per meter of branches, but did not mean an increase in accumulated productivity. Already [13] recommends that, for the exclusive production of green figs for industrialization, the plants can be conducted with 20 to 30 productive branches. 


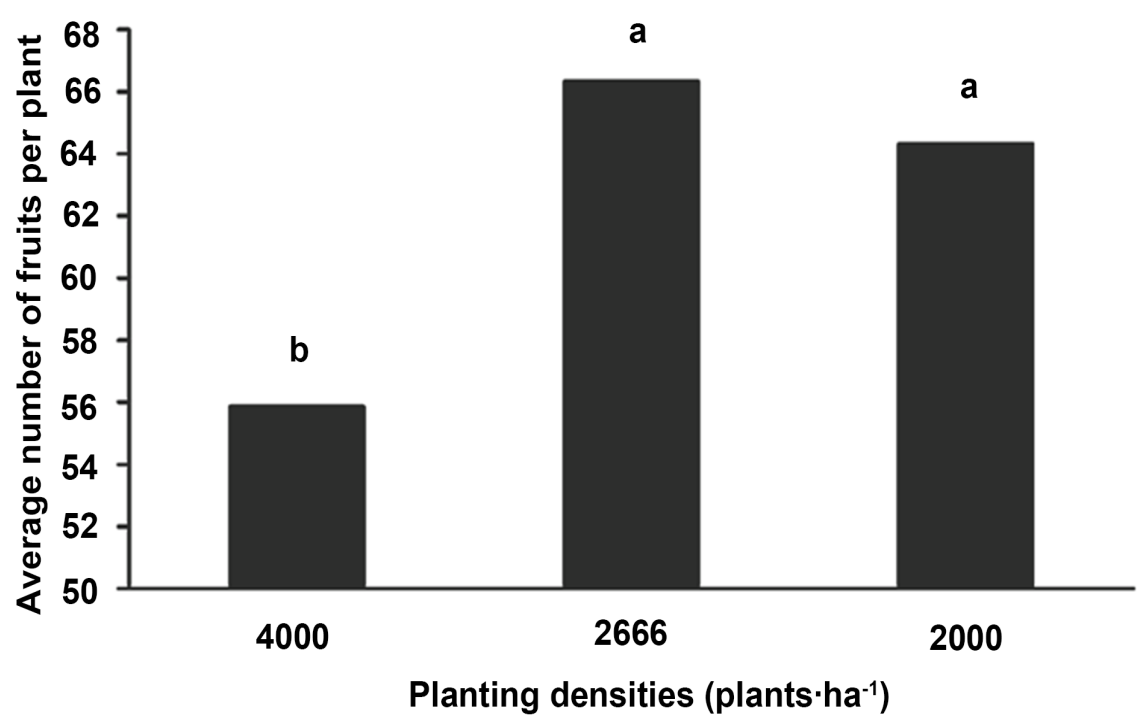

Figure 3. Average number of fruits per plant in three planting densities of fig tree cv. Roxo de Valinhos. Means followed by distinct letters on the column, differ significantly from each other by the Tukey test at the $5 \%$ level of significance. C.V. $=8.32 \%$.

Analyzing the total data of fig numbers per plant, it is verified that although the productions were relatively small, when compared with means of other producing regions, this low production can perhaps be attributed to a severe attack of Cerrugium fici, that in spite of the preventive and curative treatments applied in the crop, due to the great oscillation of temperature and humidity, could have negatively affected the crop during the crop cycle.

\subsection{Average Yield per Plant}

The results showed that the highest yields per plant were verified in the larger plant spacings ( $1.5 \mathrm{~m}$ and $2.0 \mathrm{~m}$ ) between plants (Figure 4), which correspond to the densities of 2666 plants.ha ${ }^{-1}$ and 2000 plants.ha ${ }^{-1}$, respectively. However, when the plants were cultivated in the density of ( 4000 plants.ha $\left.^{-1}\right)$, although the yield per plant was lower than in the other planting densities, when considering the number of plants per area, it is verified that the production was (4000 plants $\left.\cdot \mathrm{ha}^{-1}\right)$. Therefore, there was no damage in the production or in the quality of the figs produced at the density of ( 4000 plants $\left.\cdot \mathrm{ha}^{-1}\right)$. Similar results were verified by [14], with the peach tree crop, in which they verified that orchards conducted in greater density presented the greatest productivities. [5], evaluating the fig tree cv. Roxo de Valinhos in protected environment, pruned in three seasons and conducted with different number of branches, combined with spacing $(0.75 \times 1.90 \mathrm{~m}$ and $1.50 \times 1.90 \mathrm{~m})$, respectively, concluded that the 8 branches, combined with the spacing of $1.50 \mathrm{~m}$ in the row $\times 1.90 \mathrm{~m}$ in the interline, presented the best results, providing higher yield per plant and per hectare, without affecting the average weight of the fruits and the qualitative aspects. 


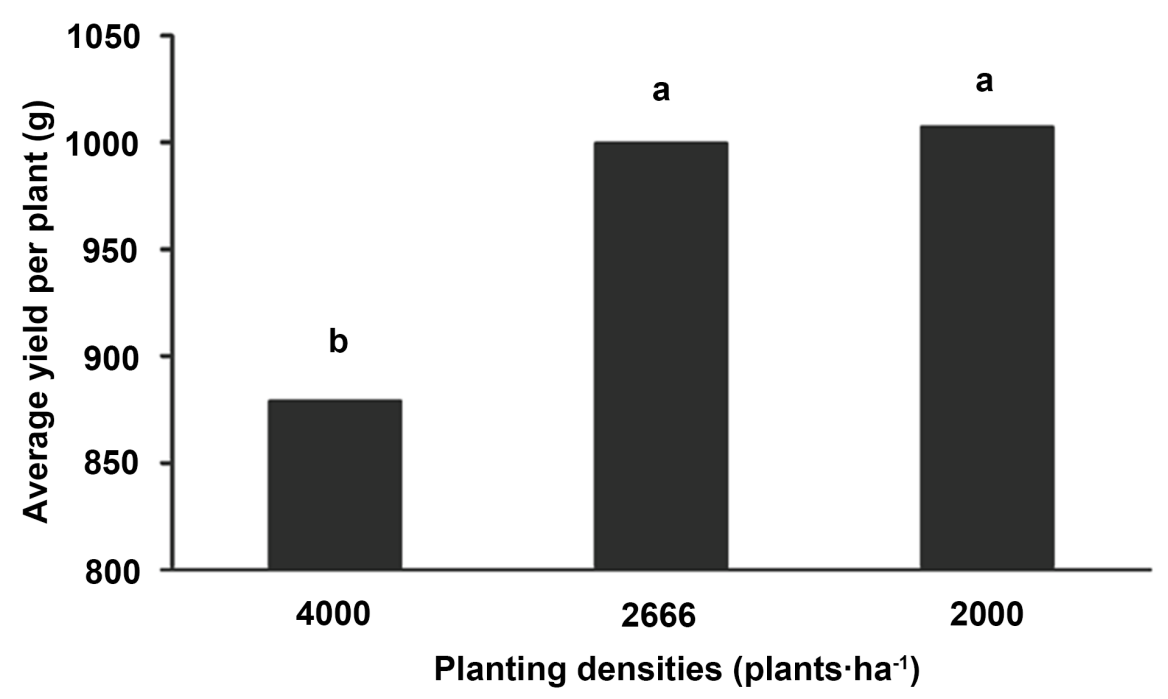

Figure 4. Average yield per plant (g) in three planting densities of fig tree cv. Roxo de Valinhos. Means followed by distinct letters on the column, differ significantly from each other by the Tukey test at the $5 \%$ level of significance. C.V. $=15.21 \%$.

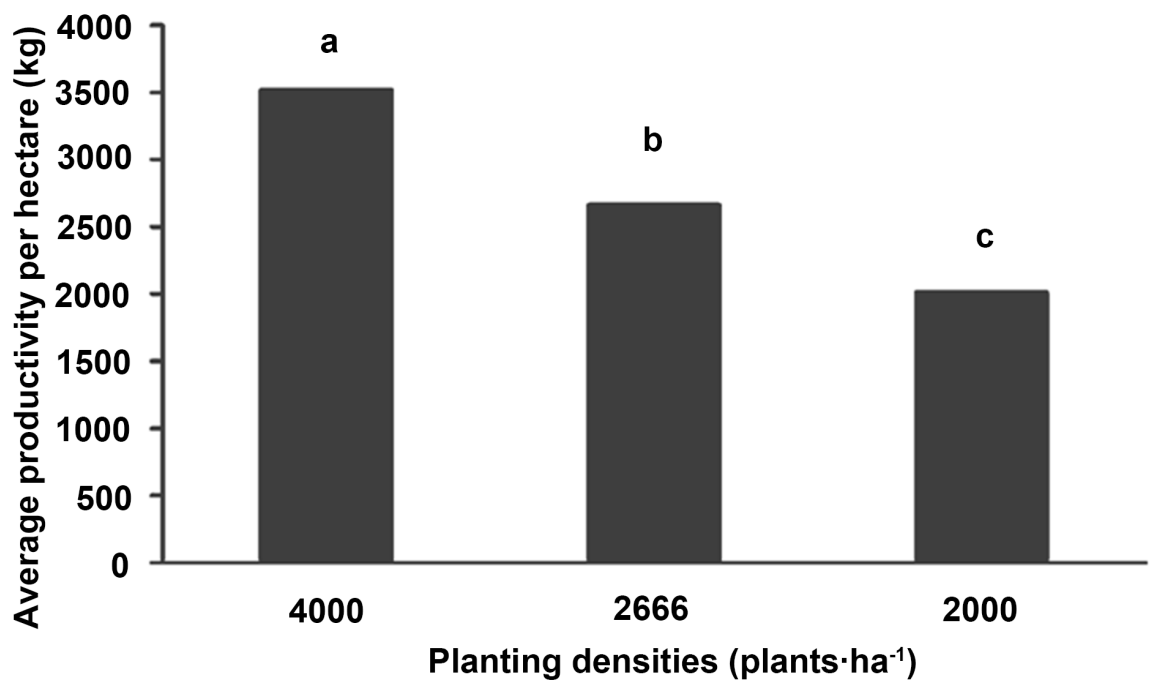

Figure 5. Average yield of figs per ha, in three planting densities of fig tree, cv. Roxo de Valinhos. Means followed by distinct letters on the column, differ significantly from each other by the Tukey test at the $5 \%$ level of significance. C.V. $=14.33 \%$.

\subsection{Average Productivity for Ha}

Regarding the estimated productivity, the significance of the results is clear (Figure 5), although already widely discussed in the other productive parameters, when the productivity per area is estimated, the differences become more evident. In this way, the cultivation of the fig tree with larger plant spacings of $1.5 \mathrm{~m}$ and $2.0 \mathrm{~m}$, with densities of 2666 plants.ha ${ }^{-1}$ and 2000 plants.ha ${ }^{-1}$, respectively, are not justified for production (4000 plants.ha ${ }^{-1}$ ), productivity was significantly higher in relation to lower planting densities, with no losses under the qualitative aspect of the fruits, even under the from the phytosanitary point of 
view, no difference was observed in relation to the incidence of diseases such as rust (Cerotelium fici), since the phytosanitary treatments were carried out with the same intensity in the three planting densities. With reference to the estimated productivity, with fruits for in natura consumption, Giacobbo et al. (2007) observed significant differences, being that fruits from plants spaced 0.5 $\mathrm{m}$ (3333 plants.ha $\left.{ }^{-1}\right)$ showing higher productivity in relation to the plants with spacing of $2.0 \mathrm{~m}$ (833 plants.ha $\mathrm{h}^{-1}$ ). The same happened with the accumulated productivity. [15] found similar results in a study on the development and production of the "Roxo de Valinhos" fig tree in four different types of pruning (long, medium, without pruning and short), associated with two spacings $(3.0 \times$ $1.5 \mathrm{~m}$ and $3.0 \times 2.5 \mathrm{~m})$, that the system conducted with greater spacing $(2.5 \mathrm{~m}$ between plants), when submitted to short pruning, is not satisfactory, since the culture presents good crown development capacity.

\section{Conclusion}

The plants conducted at a spacing of $1.0 \mathrm{~m}$ between plants and $2.5 \mathrm{~m}$ between rows, with a density of 4000 plants $\mathrm{ha}^{-1}$, provide higher productivity per area, without detriment to the vegetative development of the plants and the quality of the fruits.

\section{Conflicts of Interest}

The authors declare no conflicts of interest regarding the publication of this paper.

\section{References}

[1] FAO-Food and Agriculture Organization (2010) Fig. http://faostat.fao.org

[2] IBGE-Instituto Brasileiro de Geografia e Estatística. Municipal Agricultural Production. http://www.ibge.gov.br

[3] Norberto, P.M., Chalfun, N.N.J., Pasqual, M., Veiga, R.D. and Mota, J.H. (2001) Effect of Pruning Time, Hydrogenated Cyanamide and Irrigation upon Anticipated Production of Green Figs. Pesquisa Agropecuária Brasileira, 36, 1363-1369. https://doi.org/10.1590/S0100-204X2001001100006

[4] Bernardes, M.S. (1987) Photosynthesis in the Canopy of Cultivated Plants. In: Castro, P.R.C., Ferreira, S.O. and Yamada, T., Eds., Ecofisiologia da produção agrícola, Associação brasileira para pesquisa da potassa e do fosfato, Piracicaba, 13-45.

[5] Chaves, A. (2003) Fig tree cv. Roxo de Valinhos Submitted to Different Seasons of Pruning and Number of Branches Combined with Spacing, in Protected Environment. Dissertação (Mestrado em Agronomia), Universidade de Passo Fundo, Passo Fundo.

[6] Ferreira, D.F. (2011) Sisvar: A Computer Statistical Analysis System. Ciência e Agrotecnologia, 35, 1039-1042. https://doi.org/10.1590/S1413-70542011000600001

[7] Giacobbo, C.L., Picolotto, L., Kruger, L.R., Parisotto, E., Tibola, C. and Fachinello, J.C. (2007) Cultivation of Fig Tree Conducted in Different Four Densities of Plantation. Revista Brasileira de Agrociência, 13, 43-46. 
[8] Caetano, L.C.S., Carvalho, A.J.C., Campostrine, E., Sousa, E.F., Murakami, K.R.N. and Cereja, B.S. (2005) Effect of the Number of Productive Branches on Leaf Area Development and Fig Yield. Revista Brasileira de Fruticultura, 27, 426-429. https://doi.org/10.1590/S0100-29452005000300021

[9] Pio, R., Chagas, E.A., Campo Dall Orto, F.A. and Barbosa, W. (2007) Management for the Cultivation of the Fig Tree. Campo \& Negócio, 62-63.

[10] Bringhenti, E. (1980) Influence of the Number of Basic Branches and Irrigation on the Production of Green Fig (Ficus carica L.) of the Cultivar Roxo de Valinhos. Dissertação (Mestrado em Agronomia), Faculdade de Agronomia Eliseu Maciel, Universidade Federal de Pelotas, Pelotas.

[11] Bezerra, J.E.F., Gonzaga Neto, L., Abramof, L. and Dantas, A.P. (1986) Influence of the Number of Fruiting Branches on the Production of Green Figs in var. Roxo de Valinhos. In: Congresso Brasileiro de Fruticultura, 8, 1986, Brasília. Anais... Brasília: Embrapa-DDT/CNPq, 2, 273-279.

[12] Santos, S.C. and Corrêa, L. de S. (2000) Development and Production of the Fig Tree (Ficus carica L.), Cultivated in Selvíria-MS. Revista Brasileira de Fruticultura, 22, 213-217.

[13] Pereira, F.M. (1981) Cultura da Figueira. Livroceres, Piracicaba, 73 p.

[14] Giacobbo, C.L., Faria, J.L.C., Conto, O., Barcellos, R.F. and Gomes, F.R.C. (2003) Behavior of the Peach Tree (Prunus persica L. Batsch) cv. Chimarrita in Different Training Systems. Revista Brasileira de Fruticultura, 25, 242-244. https://doi.org/10.1590/S0100-29452003000200014

[15] Abrahão, E., Chalfun, N.N.J. and Regina, M.A. (1990) Influence of Different Types of Pruning without Development and Production of the Fig Tree (Ficus carica L.) Roxo de Valinhos. Revista Brasileira de Fruticultura, 12, 27-31. 